\title{
Treponemal serology on Bali Island, Indonesia
}

\author{
R NEY,* M F GARNER, † J L BACKHOUSE, + N WIRIA DUARSA, \\ DARWATA BREGUET, $\neq$ AND G BREGUET $\S$ \\ From the *Department of Human Genetics, CHUV, Lausanne, Switzerland; the +Institute of Clinical \\ Pathology and Medical Research, Sydney, Australia; the $¥$ Faculty of Medicine, University of Udayana, \\ Denpasar, Bali, Indonesia; and the §Department of Anthropology, University of Geneva, Switzerland
}

SUMMARY As part of a multidisciplinary study of the population of Bali, Indonesia, treponemal serology was carried out on 2452 serum samples from subjects of both sexes. Sera reactive to the Treponema pallidum immobilisation test (TPI) were found in $81(3 \cdot 3 \%)$ subjects with a male prevalence of $4 \%$ and a female prevalence of $2 \%$. All the reactive sera were from villagers. Of 1118 students sampled in various towns, none had reactive TPI tests. The prevalence of reactive sera varied greatly from one village to another; up to $50 \%$ of the sera examined were reactive. Geographical and socioeconomic analyses of the data show a strict correlation between poor socioeconomic status and high reactivity rates to the TPI test. Fifty-seven per cent of all the reactive sera originated from subjects living in two districts where yaws had recently been reported. Only three of the 1406 subjects, aged 15-29 years, had reactive sera. The reactivity rate steadily increased in the age groups 30-44, 45-59, and 60 years and over. Biological false-positive reactions occurred in $3.8 \%$ of the sera tested.

\section{Introduction}

The island of Bali $\left(115^{\circ}\right.$ longitude east $/ 8^{\circ} 30$ latitude south) is the first of the Lesser Sunda Islands from the west. Its surface area is $5600 \mathrm{~km}^{2}$ and its climate tropical, with a dry and a rainy season but a relative humidity always above $70 \%$. The average temperature is around $30^{\circ} \mathrm{C}$, with variations between day and night not exceeding $6^{\circ} \mathrm{C}$. There are important climatic variations between the north, rather dry part of the island, the wet mountainous centre, and the alluvial plains of the south. In 1980 the population was 2500000 inhabitants, with a density varying from 200 to 700 inhabitants $/ \mathrm{km}^{2}$. Most of the population practises a local Hindu religion and lives in traditional rural villages, the social structures of which have remained unchanged for many centuries. ${ }^{1}$ The tolerance to premarital or extramarital intercourse varies greatly from one community to the other, but in most cases the sexual partners belong to the same community. Traditionally there are two kinds of marriages in Bali: the union arranged by the parents and the union of two persons in love after a ritual elopement; in the second case, a large proportion of the brides are pregnant.

Address for reprints: Dr R Ney, 1041 Bretigny-sur-Morrens, Switzerland

Accepted for publication 20 June 1982
The nutritional state of the population is generally adequate. Famine has not occurred in Bali in the last decade, except in the poor areas of the east and on the island of Nusa Penida (figure).

Yaws was present throughout Bali until eradication campaigns were carried out by the Indonesian Government in the late 1950s and early 1960s using penicillin. ${ }^{2}$ These campaigns combined with the wide use of penicillin for other diseases, particularly in children, dramatically reduced the incidence of yaws. In 1980, 27 cases of yaws were reported to the Communicable Diseases Center of the Department of Health in Bali. All the cases were located in two specific areas (figure): the first one (Tejakula District) in the north-east of Bali, with one active and 10 non-active cases, the other on the island of Nusa Penida, with 15 active and one non-active cases. Both locations are among the poorest areas of Bali.

Syphilis is not endemic in Bali, probably because of its moist tropical climate. Venereal syphilis is reported in the two main towns, Denpasar and Singaraja, but its prevalence is difficult to evaluate, mainly owing to the lack of normal population samples. The only available data are those of the Communicable Diseases Center (1977-1979), ${ }^{3}$ which runs regular clinical and serological surveys (using the Venereal Disease Research Laboratory test only) among particular groups: soldiers, students, government employees, workers emigrated from 


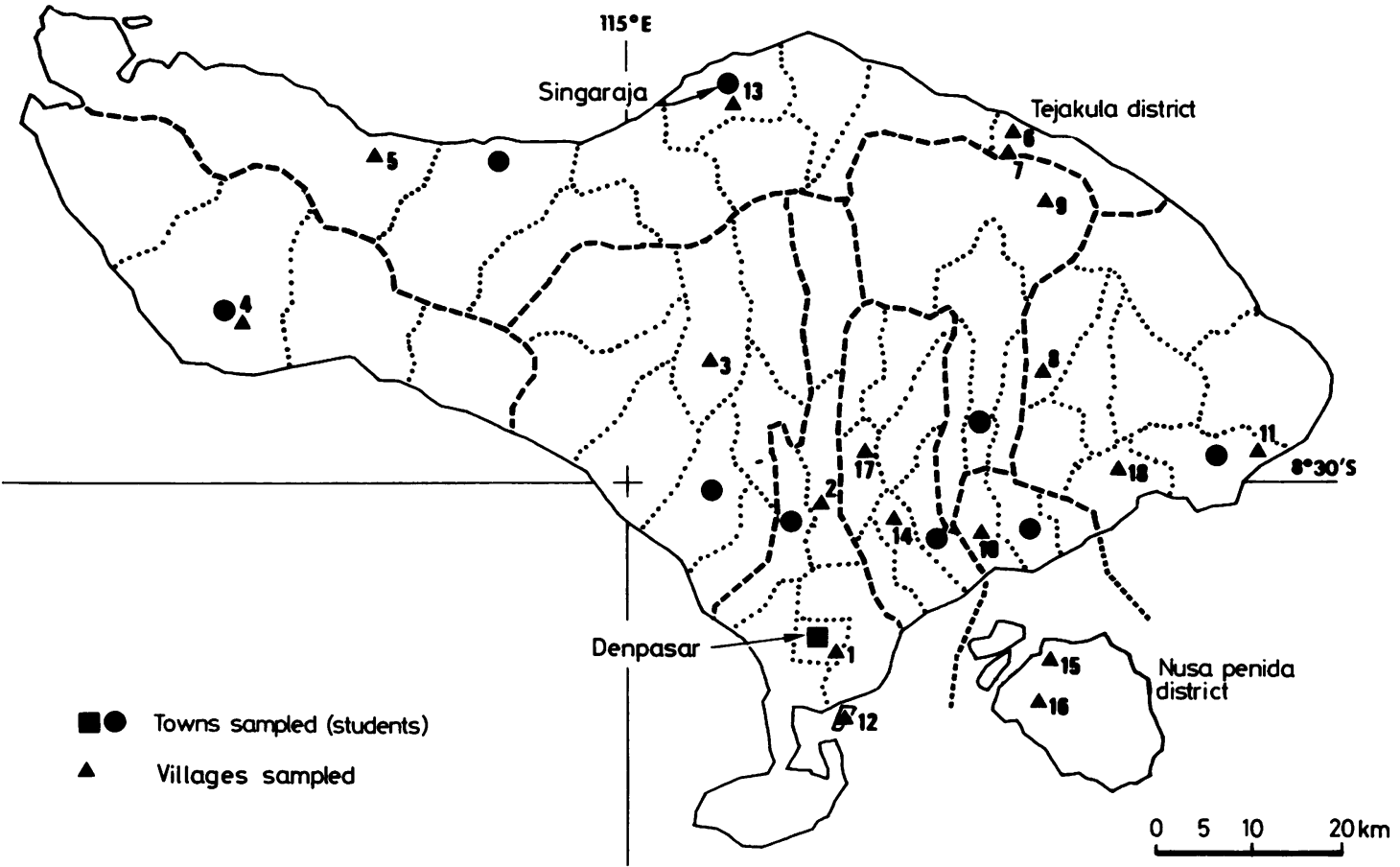

FIGURE Map of Bali, Indonesia, showing the villages sampled: (1) Renon, (2) Ayunan, (3) Penebel,

(4) Dauh Waru, (5) Grokgak, (6) Julah and Pacung, (7) Sembiran, (8) Rendang, (9) Songan,

(10) Banjar Angkan, (11) Seraya, (12) Serengan, (13) Bratan, (14) Wanayu, (15) Ped, (16) Kelumpu,

(17) Ubud, (18) Tenganan.

villages and living in the town, and prostitutes. An average of 4000 sera were tested yearly, and the annual incidence of new cases was: 1977, 2.9\%; $1978,1 \cdot 5 \%$; and $1979,0.9 \%$ of the population sampled.

\section{Patients and methods}

A multidisciplinary study of the Balinese population was undertaken between 1978 and 1981 by the department of anthropology of the University of Geneva, with the collaboration of the University of Udayana (Bali). The main goal was to study the blood polymorphism and the genetic differentiation of this population. One of the other projects undertaken was to determine the prevalence of treponemal infection in Bali.

\section{POPULATION SAMPLE}

Students (1118) of both sexes aged 16 to 29 (mean age 21.4 years for men, 20.6 years for women) were sampled in the 10 main towns of the island. Most were from upper middle-class or wealthy families and belonged to the high caste religious group. They rarely came from the poorest rural areas.
Village people (1334) of both sexes (mean age $40 \cdot 8$ years for the men and 40.7 for the women) were sampled in 19 different locations (figure) in all the regencies of the island. They were low-caste peasants living in rural areas. Their socioeconomic state was much lower than that of the students in the first group but showed great variation from village to village.

CLINICAL EXAMINATIONS

Subjects from whom blood was taken received medical care if they had any complaint, but a systematic clinical evaluation of treponematosis was not possible. The female and the male genitalia could rarely be examined. Many subjects had slight bowing of the tibiae, leg scars, or skin eruptions, but these clinical findings were difficult to interpret, especially in the older age group, as in many instances they could not be distinguished from conditions resulting from poor nutrition, previous injuries, or burns.

\section{SEROLOGY}

Blood was collected aseptically by venepuncture and sent as soon as possible by air to Switzerland, where the serum was separated and frozen within $\mathbf{4 8}$ hours of blood collection. Sera were sent frozen to the 
Institute of Clinical Pathology and Medical Research, Westmead, Australia, for treponemal antibody testing. The following tests were carried out on each specimen: Venereal Disease Research Laboratory (VDRL) slide test, fluorescent treponemal antibody absorbed (FTA-ABS) test, and Treponema pallidum immobilisation (TPI) test. A reactive TPI test result was taken to indicate past or present treponemal infection and all other results were compared with it.

\section{Results}

\section{TOTAL GROUP}

Details of reactivity to the TPI test by age and sex are shown in table I. Of the 2452 sera examined, 81 $(3 \cdot 3 \%)$ were reactive. The mean age of the reactive subjects was $49 \cdot 2$ years; the mean age of the village population sampled was $40 \cdot 8$ years. The incidence of reactive subjects steadily increased with age and reached a maximum of $11 \cdot 2 \%$ in the older age group.

\section{TOWNS AND VILLAGES}

None of the 1118 students tested were TPI reactive. This result should be compared with that of a group of 135 students from South Sulawesi (54 from Ujung Pandang and 81 from Makale), in which no sera were reactive to the TPI test. The 19 villages sampled have been grouped according to the increasing incidence of reactivity to the TPI test in table II. The incidence was higher among men than among women in all but two of the villages. In the age group 15-29 years the incidence for villagers only (without the students) was $1.0 \%$ (three reactive sera out of 288 ); $1 \cdot 1 \%$ (two of 176) of the men and $0.9 \%$ (one out of 112) of the women had reactive sera. The only area where the results were appreciably different from the rest of Bali was the island of Nusa Penida, $15 \mathrm{~km}$ offshore from the mainland. It is a dry sandstone plateau inhabited by a population living a hard and poor life. The reactivity rates of this population in Kelumpu and Ped was $8 \cdot 3 \%$ in the age group $15-29$ years; $46.4 \%$ in the age group $30-44$ years; $62.5 \%$ in the age group $45-59$ years; and $83.3 \%$ in the age group 60 years and over. There was no difference in the incidence of reactivity between men and women (26 reactive sera from 52 men, and eight reactive sera from 18 women).

\section{COMPARISON OF TEST RESULTS}

For the purpose of this survey the TPI test was regarded as the most specific test for treponemal infection ${ }^{4}$; the results of other tests were compared with it. The number of sera reactive in each test were: TPI, 81; FTA-ABS, 92; and VDRL, 149. There were 49 sera which were reactive in all three tests. Only six of these showed VDRL titres of $\geqslant 8$. The mean age of these six subjects was $48 \cdot 3$ years, which was similar to the mean age of all those subjects with reactive sera in the TPI test $(49 \cdot 2$ years).

All sera reactive in the TPI test were also reactive

TABLE I TPI test results in relation to age and sex in population studied

\begin{tabular}{|c|c|c|c|c|c|c|c|c|c|}
\hline \multirow[b]{3}{*}{ Age (years) } & \multicolumn{3}{|l|}{ Both sexes } & \multicolumn{3}{|l|}{ Men } & \multicolumn{3}{|l|}{ Women } \\
\hline & \multirow{2}{*}{$\begin{array}{l}\text { No of } \\
\text { sera tested }\end{array}$} & \multicolumn{2}{|c|}{ TPI-reactive } & \multirow{2}{*}{$\begin{array}{l}\text { No of } \\
\text { sera tested }\end{array}$} & \multicolumn{2}{|c|}{ TPI-reactive } & \multirow{2}{*}{$\begin{array}{l}\text { No of } \\
\text { sera tested }\end{array}$} & \multicolumn{2}{|c|}{ TPI-reactive } \\
\hline & & No & $\%$ & & No & $\%$ & & No & $\%$ \\
\hline $\begin{array}{r}0-14 \\
15-29 \\
30-44 \\
45-59 \\
60-+ \\
\text { Total }\end{array}$ & $\begin{array}{r}22 \\
1406 \\
491 \\
345 \\
188 \\
2452\end{array}$ & $\begin{array}{r}0 \\
3 \\
26 \\
31 \\
21 \\
81\end{array}$ & $\begin{array}{r}0.0 \\
0.2 \\
5 \cdot 3 \\
9 \cdot 0 \\
11 \cdot 2 \\
3.3\end{array}$ & $\begin{array}{r}14 \\
1021 \\
278 \\
202 \\
127 \\
1642\end{array}$ & $\begin{array}{r}0 \\
2 \\
20 \\
23 \\
20 \\
65\end{array}$ & $\begin{array}{r}0.0 \\
0.2 \\
7.2 \\
11.4 \\
15.7 \\
4.0\end{array}$ & $\begin{array}{r}8 \\
385 \\
213 \\
143 \\
61 \\
810\end{array}$ & $\begin{array}{r}0 \\
1 \\
6 \\
8 \\
1 \\
16\end{array}$ & $\begin{array}{l}0 \cdot 0 \\
0 \cdot 3 \\
2 \cdot 8 \\
5 \cdot 6 \\
1 \cdot 6 \\
2 \cdot 0\end{array}$ \\
\hline
\end{tabular}

TABLE II Number and percentage of sera reactive to the TPI test by sex in the village populations

\begin{tabular}{|c|c|c|c|c|c|c|c|c|c|c|}
\hline \multirow{3}{*}{$\begin{array}{l}\% \text { of } T P I \\
\text { reactivity }\end{array}$} & \multirow[b]{3}{*}{ Villages* } & \multicolumn{3}{|c|}{ Both sexes } & \multicolumn{3}{|l|}{ Men } & \multicolumn{3}{|c|}{ Women } \\
\hline & & \multirow{2}{*}{$\begin{array}{l}\text { No of } \\
\text { sera } \\
\text { tested }\end{array}$} & \multicolumn{2}{|c|}{ TPI-reactive } & \multirow{2}{*}{$\begin{array}{l}\text { No of } \\
\text { sera } \\
\text { tested }\end{array}$} & \multicolumn{2}{|c|}{ TPI-reactive } & \multirow{2}{*}{$\begin{array}{l}\text { No of } \\
\text { sera } \\
\text { tested }\end{array}$} & \multicolumn{2}{|c|}{ TPI-reactive } \\
\hline & & & No & $\%$ & & No & $\%$ & & No & $\%$ \\
\hline $\begin{array}{l}0 \\
1-5 \\
6-20 \\
+20\end{array}$ & $\begin{array}{l}5,8,13,14,17 \\
1,3,7,9,10,18 \\
2,4,6,11,12 \\
15,16\end{array}$ & $\begin{array}{r}320 \\
609 \\
335 \\
70\end{array}$ & $\begin{array}{r}0 \\
17 \\
30 \\
34\end{array}$ & $\begin{array}{r}0 \cdot 0 \\
2 \cdot 8 \\
9 \cdot 0 \\
48 \cdot 6\end{array}$ & $\begin{array}{r}179 \\
356 \\
210 \\
52\end{array}$ & $\begin{array}{r}0 \\
16 \\
23 \\
26\end{array}$ & $\begin{array}{r}0.0 \\
4 \cdot 5 \\
11 \cdot 0 \\
50 \cdot 0\end{array}$ & $\begin{array}{r}141 \\
253 \\
125 \\
18\end{array}$ & $\begin{array}{l}0 \\
1 \\
7 \\
8\end{array}$ & $\begin{array}{r}0 \cdot 0 \\
0 \cdot 4 \\
5 \cdot 6 \\
44 \cdot 4\end{array}$ \\
\hline
\end{tabular}

* See figure for location of villages corresponding to the numbers given 
in the FTA-ABS test. Of these 81 sera, 49 were reactive and 32 non-reactive in the VDRL test. The results of the TPI and FTA-ABS tests were in disagreement in 11 sera, in which the FTA-ABS test was reactive and the TPI test non-reactive. The VDRL results in these 11 sera were reactive in seven and non-reactive in four. The mean age of these 11 subjects was 43.0 years. Biological false-positive reactions, with only the VDRL being reactive, were found in $92(3.8 \%)$ of the 2452 sera tested; the mean age of these subjects was $36 \cdot 8$ years.

\section{Discussion}

Despite the inadequacy of serological tests to differentiate between infection with yaws and syphilis, the results of this survey provide some useful information. No sera were reactive to the TPI test in the small group of children and in almost all of the large group of young adults (15-29 years). Yaws is mainly a disease of children, and thus these groups had presumably not been exposed to this infection; this indicates that the yaws campaigns nearly eradicated the disease 25 years ago. Another important fact is that these groups are also free of venereal syphilis. There is a steady increase in the reactivity rate to the TPI test in the age groups $30-44$, 45-59, and over 60 years. This could indicate a spontaneous decrease in the incidence of yaws in the 1940s and 1950s before the penicillin treatment campaigns, as was observed for syphilis in the United Kingdom. ${ }^{6}$

The geographical distribution of the villages with a high reactivity rate to the TPI test corresponded with the two areas where active yaws had recently been reported (personal communication). There was also a distinctive correlation between poverty and a high reactivity rate. The population of these villages was the most unlikely to have had contact with the possible foci of syphilis in the two main towns, Denpasar and Singaraja.

Unlike other Asian towns prostitution associated with tourism is almost non-existent in Bali.

The low proportion of TPI-reactive subjects with high VDRL titres suggests that latent or previous inactive treponemal infection was prevalent among the TPI-reactive subjects. The analysis of the data strongly suggests that most of them had been infected with yaws in the past. The incidence of venereal syphilis was probably very low in the population tested.

The problem of sera reactive in the FTA-ABS but non-reactive in the TPI test is difficult. Mackey et al ${ }^{5}$ concluded that the FTA-ABS test was more sensitive than the TPI test, particularly in treponemal infections of long duration, but that its specificity was not absolute.

Biological false-positive reactions occurred frequently in this survey $(3 \cdot 8 \%)$ whereas Jegathesan et $a l^{7}$ found an incidence of $1 \cdot 3 \%$ among 10096 expectant mothers in Malaysia and the incidence among 21924 sera at the Institute of Clinical Pathology and Medical Research, Westmead, Australia, was $0 \cdot 2 \% .^{8}$ In the survey on Kar Kar Island, New Guinea, Garner et al ${ }^{9}$ found a rate of $1 \cdot 7 \%$. The causes of biological false-positive reactions are multiple. ${ }^{7}$ Possibly the difference in rates in the age group 16-29 years between men $(2 \cdot 0 \%)$ and women $(11 \cdot 2 \%)$ is due to repeated pregnancies in women.

This survey was funded by the Swiss National Fund for Scientific Research (grant 3888) and partially assisted by a grant from the World Health Organisation (grant G3/181/105A). We are grateful to the Indonesian Institute of Sciences (LIPI) for its help and support.

\section{References}

1. Ramseyer U. The Art and Culture of Bali. London: Oxford University Press, 1977.

2. Harahap M. Sexually transmitted diseases in Indonesia. $\mathbf{B r} J$ Vener Dis 1980; 56:282-4.

3. Directorate of Communicable Diseases Center. Annual Report of the Department of Health of the Province of Bali (1978-1979), Bali, 1980.

4. Wilkinson AE, Rayner CFA. Studies on the fluorescent treponemal antibody (FTA) test. Br J Vener Dis 1966; 42: 8-15.

5. Mackey DM, Price V, Knox JM, Scotti A. Specificity of the FTA-ABS test for syphilis. $J A M A$ 1969; 207:1683-5.

6. Blount JH, Holmes KK. Epidemiology of syphilis and nonvenereal treponematosis. In: Johnson RC, ed. The Biology of Parasitic Spirochetes. New York: Academic Press, 1976: 157-76.

7. Jegathesan M, Fan YH, Ong KJ. Seroreactivity to syphilis in Malaysian blood donors and expectant mothers. South-east Asian J Trop Med Pub Hlth 1975;3:413-8.

8. Garner MF. The biological false-positive reactions to serological tests for syphilis in blood donors. J Clin Pathol 1970; 23:31-4.

9. Garner MF, Hornabrook RW, Backhouse JL. Prevalence of yaws on Kar Kar Island, New Guinea. $\mathrm{Br} J$ Vener Dis 1972;48:350-5. 